\title{
Forensik Digital Berdasarkan Citra Mikroskop untuk Autentikasi Arsip Tercetak
}

\section{$\begin{array}{llllllll}\text { I } & \mathbf{N} & \mathbf{T} & \mathbf{I} & \mathbf{S} & \mathbf{A} & \mathbf{R} & \text { I }\end{array}$}

Pembuktian keaslian arsip tercetak dari suatu printer merupakan suatu kebutuhan untuk menentukan keabsahan suatu produk teknologi informasi terutama untuk mesin cetak. Tujuan penelitian ini adalah untuk melakukan autentikasi arsip tercetak berdasarkan bentuk partikel toner yang menempel pada huruf tercetak dari setiap jenis dan merk printer. Studi ini menggunakan metode pendekatan forensik digital melalui citra digital mikroskop dari arsip tercetak yang dianalisis menggunakan FIJI/ ImageJ dengan pendekatan histogram dan dikombinasikan dengan analisis jumlah partikel huruf dari setiap merk printer. Hasil eksperimen menunjukkan perbedaan yang signifikan dari setiap jenis printer untuk menentukan sumber arsip asli atau palsu yang dikeluarkan oleh suatu institusi atau lembaga tertentu.

\section{$\begin{array}{llllllll}A & B & S & T & R & A & C & T\end{array}$}

The authenticity of printed archives is an essential evidence to determine the validity of an information technology product, especially technology printing. This purpose of this study is to authenticate printed archives based on toner particles attached to the printed letters among printer types. The research method is a digital forensic through microscopic images from printed archives which is analyzed using FIJI/ ImageJ. It is used histograms with a graphical display of data from the number of particles from each printer brand. The experimental results show significant differences from each type of printer to determine sources of original or fake archives issued by a particular institution.
PENULIS

Firzanatusalma Rafiza Yuadi

SMAIT Misykat Al-Anwar Jombang firzanatusalma@mail.com

\section{KATA KUNCI}

arsip tercetak, forensik digital, imageJ, autentikasi

\section{KEY WORDS}

authentication, digital forensics, imageJ, printed archives

Submitted: 08/06/2020

Reviewed: 02/07/2020 Accepted: 16/07/2020 


\section{PENGANTAR}

\section{Latar Belakang Masalah}

Arsip yang tercetak dari luaran printer sangat banyak digunakan oleh instansi swasta maupun negeri sejak tahun 1980-an. Penggunaan arsip dalam bentuk kertas tidak hanya tersebar luas di bidang pendidikan, keuangan, perjanjian sewa, faktur/ tagihan pembelian, dan bahkan putusan pengadilan. Hal ini disebabkan arsip sebagai identitas atau surat berharga sangat penting bagi pemiliknya. Namun demikian, dengan kemajuan dunia penerbitan dan editing yang didukung oleh teknologi informasi, arsip ataupun dokumen tercetak rawan digandakan atau dipalsukan untuk kepentingan orangorang tertentu yang tidak bertanggung jawab. Banyaknya penggunaan arsip tercetak menimbulkan tantangan serius bagi penegak hukum untuk menentukan autentikasi arsip asli atau palsu.

Pemalsuan dokumen maupun arsip sering terjadi di Indonesia. Hal yang sering dilakukan adalah mengganti identitas sesuai dengan permintaan. Pemalsuan KTP ini juga merupakan penyetingan tanda tangan di perangkat komputer (Fanani, 2020). Selain itu, Polisi juga membekuk tiga orang pemalsu dokumen negara. Para tersangka memalsukan dokumen negara bagi mereka yang ingin membuat paspor (Saputra, 2020). Demikian pula, Velarosdela (2019) seorang tersangka berinisial HMY tertangkap polisi karena biasa memalsukan dokumen negara seperti ijazah, SIM, KTP, dan Kartu Izin Tinggal Sementara (KITAS). Dunia digital saat ini, mengamankan berbagai bentuk konten sangat penting dalam rangka melindungi hak cipta dan memverifikasi keaslian. Kerugian perdagangan luar negeri karena pembajakan buku antara tahun 2015 sampai dengan 2019 diperkirakan antara $\$ 633$ juta sampai dengan $\$ 695$ juta per tahun. Selain itu, materi cetak adalah aksesori langsung yang digunakan untuk banyak kegiatan kriminal seperti pemalsuan atau pengubahan dokumen untuk tujuan identitas atau pencatatan transaksi. Bahan cetakan juga dapat digunakan melakukan kegiatan ilegal. Contohnya termasuk manual instruksi, daftar nama tim, catatan pertemuan, dan korespondensi. Kedua kasus, kemampuan untuk mengidentifikasi perangkat atau jenis perangkat yang digunakan untuk mencetak atau memindai materi tersebut akan memberikan bantuan yang berharga bagi penegak hukum dan badan intelijen.

Studi tentang otentifikasi dokumen tercetak telah dilakukan dengan cara analisis kimia toner dan penggunakan analisis tekstur dengan penggunaan machine learning cenderung dibutuhkan kemampuan programming yang mumpuni dan kadang menyebabkan kerusakan pada sebagian atau seluruh 
dokumen yang diselidiki. Aspek penting dalam pendeteksian pemalsuan menggunakan investigasi digital dimaksudkan untuk memastikan bahwa sumber dokumen cetak tidak dipalsukan. Petunjuk tentang jenis, merek, atau model mesin cetak dapat membantu membedakan dokumen palsu dari besar volume dokumen cetak seperti dalam kasus pemalsuan mata uang seperti yang dikemukakan Chiang (2004: 145). Untuk mengidentifikasi sumber dan autentikasi dokumen cetak, beberapa metode berdasarkan gambar digital pemrosesan telah diusulkan oleh para peneliti.

Penelitian ini mengusulkan untuk pengembangan strategi untuk identifikasi printer berdasarkan pemeriksaan arsip tercetak menggunakan mikroskop digital sederhana. Strategi ini meliputi analisis jenis printer dengan menemukan pola intrinsik dalam arsip tercetak yang merupakan karakteristik dari printer berdasarkan model atau merk pabrikan tertentu. Tanda intrinsik yang melekat pada cetakan membutuhkan pemahaman dan pemodelan mekanisme printer serta pengembangan analisis tekstur ImageJ/ Fiji untuk mendeteksi tanda tersebut pada halaman yang dicetak dengan konten yang ada.

\section{Rumusan Masalah}

Penulisan karya ini, menetapkan satu rumusan masalah yang diharapkan dapat menjawab masalah pada latar belakang. Oleh karena itu, dengan melihat fenomena dan permasalahan dalam teknologi percetakan khususnya arsip tercetak dapat dirumuskan satu pertanyaan, bagaimana metode autentikasi arsip yang tepat dan mudah untuk menentukan keaslian suatu berkas surat yang dicetak menggunakan printer merk dan jenis tertentu?

\section{Tujuan Penelitian}

Penelitian ini bertujuan untuk melakukan autentikasi arsip tercetak berdasar pada bentuk partikel toner yang menempel pada huruf tercetak dari setiap merk printer dan tipenya.

\section{Metodologi Penelitian}

Pada beberapa studi printer dan dokumen tercetak, para peneliti menyelidiki melalui pendekatan machine learning yang sebelumnya diekstrak menggunakan beberapa feature extraction sebelum diklasifikasi dan ditentukan jenisnya seperti yang dilakukan oleh Milkilineni (2004: 455-466). Tulisan ini menggunakan pendekatan investigasi gambar mikro digital yang diolah dengan software Fiji/ ImageJ untuk menganalisis partikel toner. Berikut ini adalah gambar langkah-langkah yang harus dilakukan untuk autentikasi arsip tercetak.

Pada Gambar 1 dijelaskan mengenai langkah-langkah yang 

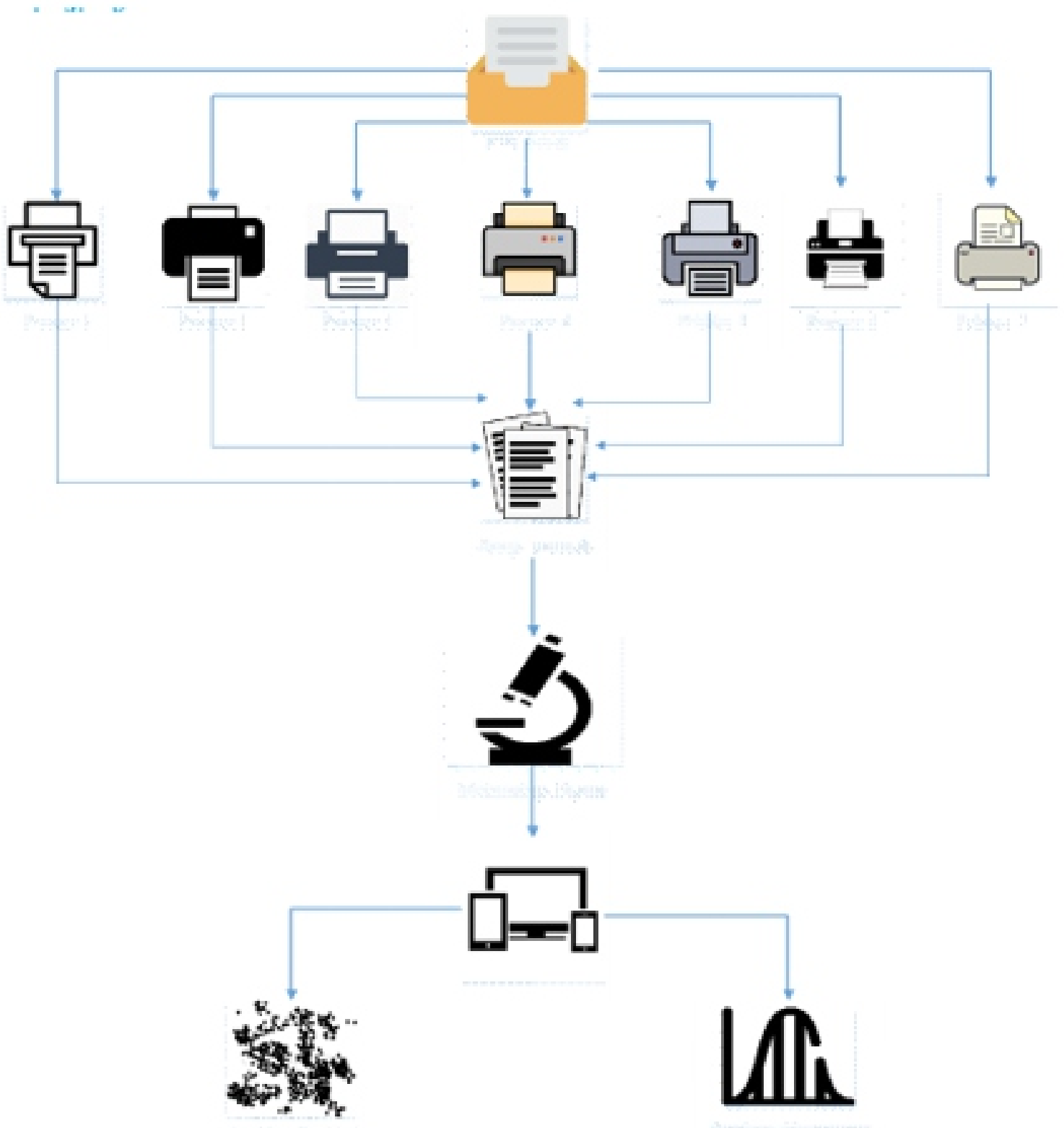

Gambar 1 Langkah autentikasi arsip tercetak Sumber Gambar: Analisis penulis, 2020

dilakukan dalam autentikasi arsip tercetak.

1. Menyiapkan arsip dalam bentuk digital word;

Arsip yang digunakan untuk penelitian ini adalah arsip surat yang dikeluarkan oleh SMAIT Misykat Al-
Anwar Jombang. Arsip yang disiapkan harus dalam bentuk arsip tercetak karena penelitian ini menggunakan media tercetak.

2. Mencetak dengan menggunakan printer yang berlainan jenis;

Berlainan jenis diartikan bahwa arsip 
dalam bentuk digital word yang telah disiapkan sebagai media tercetak akan dicetak dengan beberapa printer yang berbeda.

Pada investigasi dokumen tercetak telah ditentukan 7 jenis printer toner. Penelitian ini menggunakan 7 printer berbeda. Printer dengan merk yang sama namun dengan spesifikasi berbeda akan memberikan hasil yang berbeda pula. 7 printer yang akan digunakan adalah sebagai berikut:

a. HP Color LaserJet CM2320fxi $\mathrm{mfp}$

Konsumsi daya, spesifikasi listrik, dan emisi akustik, dimensi produk dengan kartrid toner. Konfigurasi teruji: HP Color LaserJet CM2320n, mencetak pada kertas ukuran A4 pada 20 ppm dalam mode simpleks.

b. LaserJet P2015d

Kemampuan dan kapasitas kecepatan cetak pada printer HP LaserJet P2015: 27 Emulasi level 3 postscript HP 132 Apendiks C. Spesifikasi fisik dengan lebar= $350 \mathrm{~mm}$, kedalaman $=361 \mathrm{~mm}$, tinggi $=256 \mathrm{~mm}$, berat (dipasangi efisiensi berkapasitas 3.000 halaman).

c. HPLaserjet Pro 4300

Spesifikasi teknologi laser monokrom dengan kecepatan tinggi mencapai HP 4200/ 4250/
$4300 / 4350=35 / 45 / 45 / 55 \mathrm{ppm}$ dengan memori prosesor $48-96$ MB, 512 MB Max / 300-460 Mhz dan resolusi cetak 1200 dpi.

d. LaserJet Pro 400 Color M451 dn Spesifikasi printer ini adalah kartrid pra-instal, cetak dari USB, kualitas laser luar biasa, hasil profesional, ukuran kecil, mencetak cepat, printer fungsi tunggal, paling terjangkau, pencetakan mono dengan processor $600 \mathrm{mhz}$, dan memori $384 \mathrm{MB}$.

e. HP Color LaserJet CP3525dn

Printer jenis ini termasuk printer laserjet berwarna dengan memori 256 MB dengan kecepatan cetak hitam putih dan warna hingga 30 ppm. Port USB 2.0 kecepatan tinggi, slot ekspansi EIO untuk jaringan, penyimpanan, dan opsi konektivitas opsional.

f. HP LaserJet 1300

Pada saat mencetak, halaman pertama keluar dalam waktu kurang dari 10 detik. Resolusi 600 x 2 dpi (FastRes 1200) dengan 8 MB RAM dan tabung tinta cetak untuk 2.500 halaman.

g. HP LaserJet 4200tn

Laser monokrom dengan kecepatan cetak: 33 ppm - A4 (8,25 inci $x$ 11,7 inci), hingga 35 ppm - B / W - A4 (8,25 inci x 11,7 


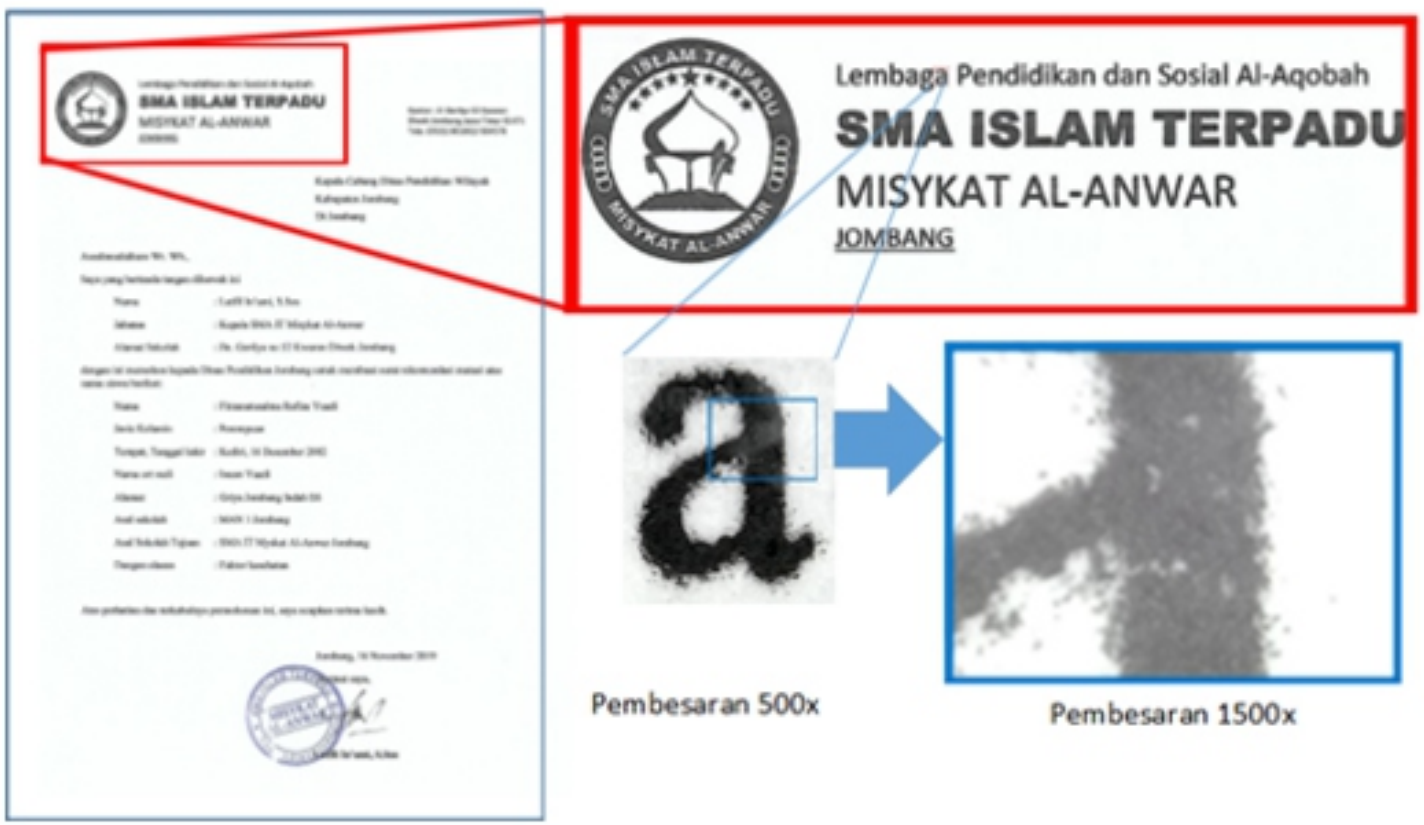

Gambar 2 Citra mikroskop untuk huruf "a"

Sumber: Arsip tercetak SMAIT Al-Misykat

inci), dan maksimal resolusi (B \& W) $1200 \mathrm{dpi}$.

3. Arsip tercetak yang dihasilkan dari 7 printer berbeda sebelumnya diteliti dengan menggunakan mikroskop digital. Mikroskop digital yang digunakan adalah $A M C a p$ microscope yang telah dilengkapi dengan penyimpanan gambar dalam format JPG/ BMP. Langkah ini menghasilkan citra dari media yang digunakan seperti pada gambar 2 .

4. Citra digital yang sudah dihasilkan diteliti kembali hingga menghasilkan penampakan tekstur dari media arsip tercetak yang telah diteliti pada beberapa proses penelitian sebelumnya. Analisis yang dilakukan adalah analisis histogram dan analisis partikel. Hasil analisis histogram, grafik ditampilkan dengan berbagai periode waktu dalam bentuk batangan dan analisis partikel menunjukkan definisi ukuran partikel dan distribusi ukuran partikel.

Untuk melakukan serangkaian langkah seperti gambar tersebut dibutuhkan beberapa bahan untuk percobaan, yaitu: pertama, arsip huruf "a" yang ditulis dengan Microsoft Word dicetak dengan 7 jenis printer yang berbeda. Eksperimen menggunakan printer dengan 7 brand dan jenis yang berbeda seperti yang disebutkan sebelumnya. Kedua, USB digital Microscope dengan magnifikasi 500x dan 
1500x dengan light source 8 LED dengan Hardware Komputer Compaq Presario CQ43 yang didukung Windows XP. Serta ketiga, perangkat lunak Fiji/ ImageJ yaitu paket pemrosesan gambar opensource berdasarkan ImageJ untuk mengolah citra gambar saos. Fiji mengakumulasikan fungsi yang cukup untuk menarik para ilmuwan dari berbagai bidang, seperti biologi sel, parasitologi, genetika, ilmu kehidupan pada umumnya ilmu material dan lain-lain.

\section{Kerangka Pemikiran}

Beberapa metode untuk mengidentifikasi dokumen atau arsip memerlukan sampel yang diekstraksi dari dokumen eksperimen yang dilakukan oleh para peneliti forensik digital untuk melakukan identifikasi arsip. Aspek terpenting dari metode tersebut adalah tersedianya perangkat laboratorium khusus, peralatan, dan metode khusus. Para ahli mempersiapkan, memanipulasi, dan menganalisis sampel dokumen tercetak dengan tingkat yang sama menggunakan teknik berbasis computer vision dan membutuhkan versi dokumen yang dipindai melalui pendekatan tertentu.

Beberapa teknik computer vision untuk identifikasi printer laser dalam literatur menggunakan pendekatan serupa (Kurniati, 2017). Para peneliti berbasis halftone atau pola titik-titik kecil dari suatu toner yang menempel menunjukkan perbedaan warna dari suatu huruf dan hanya diterapkan pada dokumen warna berupa gambar bukan huruf. Ada teknik lain yang bertujuan mengidentifikasi printer Ferreira (2017: 105-125) dan teknik lainnya berbasis tekstur dan sedang diterapkan pada dokumen teks. Wu dkk. (2015: 861-865) juga menggunakan distorsi geometris untuk mengidentifikasi sumber printer. Mereka memodelkan transformasi proyektif yang mewakili distorsi geometrik menggunakan pusat huruf dalam dokumen yang dipindai dan versi gambar (TIFF). Model ini diselesaikan menggunakan kuadrat terkecil dekomposisi nilai singular dan penghapusan outlier. Subset dari parameter model kemudian digunakan sebagai input fitur vektor dengan menggunakan klasifikasi pembelajaran mesin (machine learning).

Milkilineni dkk. (2004: 455-466) mengusulkan penggunaan tekstur deskriptor berdasarkan statistik dari matriks kejadian bersama tingkat abu-abu gray level co-occurrence matrices (GLCM) untuk mengidentifikasi sumber dokumen teks. Teknik ini menggunakan dokumen yang dipindai pada 2400 dpi dengan piksel delapan bit dan menggunakan sampel huruf "e" yang diekstraksi dengan piksel yang berbeda. Setelah itu, 22 statistik GLCM diekstraksi per karakter. Setiap vektor fitur 
diklasifikasikan secara individual, menggunakan 5 tetangga terdekat classifier. Akhirnya klasifikasi menggunakan mesin pembelajaran dari setiap klasifikasi huruf. Karya ini diperpanjang oleh Kurniati (2017:13) dengan menggunakan support vector machine (SVM).

Bulan et al. (2009: 1401-1404) menggunakan korelasi antara geometris distorsi yang disebabkan oleh printer laser untuk mengidentifikasi mereka. Artefak ini terdeteksi dengan mengurangi area yang harus dicetak printer dan area yang dicetak secara efektif. Teknik ini mengekstrak geometris huruf tercetak dengan memperkirakan posisi titik pada halftone di printer pada set pelatihan dan membandingkan, dengan korelasi, posisi poin dalam tes. Shang et al. (2015) mengusulkan ekstraksi Vektor fitur 9d dari dokumen yang dipindai berdasarkan pada Benford's law. Fitur-fitur ini adalah distribusi probabilitas digit pertama Koefisien Discrete Cosine Transform (DCT) dari blok multi-ukuran. Demikian juga, Tsai dkk. (2018: 1-45) menggabungkan statistik GLCM matriks dan sub-band transformasi wavelet. Ini digunakan pada kasus tertentu dalam mengidentifikasi sumber printer laser dari suatu dokumen yang berisi karakter Cina. Ekstraksi pola tekstur terjadi pada karakter tertentu dari bahasa Cina setelah dokumen dipindai. Kemudian, dalam
Jung (2014), diusulkan solusi berdasarkan pengelompokan dan jarak Euclidean untuk mengidentifikasi dokumen sebagai hasil dari printer yang tidak dikenali. Kerangka Pemikiran berisi teori atau konsep yang digunakan untuk menganalisis objek penelitian.

Studi tentang analisis partikel pada toner dan tinta printer dilakukan Hryt Senko dkk. (2017: 12) menunjukkan kemungkinan menggunakan pencetakan pada kertas, dalam Hryt Senko (2017: 9) perspektif sablon dipelajari untuk cetakan dan komposisi tinta dengan nanopartikel untuk teknik pencetakan tertentu dibahas dalam kajian tersebut. Teknik pencetakan memungkinkan pembuatan arsip dan dokumen dengan biaya rendah dan dalam waktu cepat dibandingkan dengan mesin ketik atau cara konvensional lainnya. Jika dibandingkan dengan teknik pencetakan lain, pencetakan inkjet sudah digunakan untuk mencetak tanggal pembuatan, tanggal kadaluarsa, dan data teknis lainnya ke dalam dokumen cetak yang kira-kira sama dengan dokumen yang dibuat. Penggunaan pencetakan inkjet juga dimungkinkan untuk aplikasi label fungsional pada kemasan, seperti yang diperdebatkan dalam Jung (2017: 1303) bahwa pencetakan inkjet memungkinkan untuk menghindari pengadaan kembali yang mahal dari suatu perusahaan untuk produksi jenis kemasan seperti itu. Seperti disebutkan dalam Hryt Senko (2017: 12) 
selain dari label dokumen fungsional seperti itu, gambar yang dicetak dengan sifat terbatas dapat digunakan untuk tujuan keamanan supaya tidak dipalsukan. Ini juga merupakan aplikasi prospektif dari tinta cetak inkjet berdasarkan karbon nanopartikel.

\section{PEMBAHASAN}

Pada pembahasan dijelaskan hasil eksperimen yang dilakukan untuk autentikasi arsip tercetak berdasarkan jenis tipe printer. Hasil eksperimen disajikan dalam hasil eksperimen dari citra mikroskop untuk 50 kali pembebesaran dan 1500 pembesaran.

Tabel 1 Citra digital mikro untuk dokumen tercetak dengan pembesaran 500x

\begin{tabular}{|c|c|c|c|}
\hline Merk Printer & Citra Huruf "a" $500 x$ & $\begin{array}{c}8 \text { bit threshold Serbuk } \\
\text { Toner }\end{array}$ & $\begin{array}{l}\text { Jumlah } \\
\text { Partikel }\end{array}$ \\
\hline HP LaserJet 4200tn & & & 18 \\
\hline $\begin{array}{c}\text { HP Color LaserJet CM2320 } \\
\text { fxi }\end{array}$ & & & 25 \\
\hline Las erJet P2015d & & & Ď \\
\hline HP Las erJet 4300 & & & 1 \\
\hline $\begin{array}{c}\text { Las erJet Pro } 400 \text { Color } \\
\text { M451dn }\end{array}$ & & & 5 \\
\hline HP Color LaserJet CP3525dn & & & 3 \\
\hline HP Las erJet 1300 & & & 7 \\
\hline
\end{tabular}

Sumber: Visualisasi Digital Microscope 


\section{Hasil Eksperimen}

Berdasarkan serangkaian uji coba terhadap dokumen tercetak, tulisan ini mengkhususkan pada hasil cetakan dari 7 printer yang berbeda. Penelitian menggunakan huruf "a" yang diketik menggunakan $M S$ Word yang menggunakan ukuran Times New Roman dengan ukuran 10 pt dan kemudian dicetak. Hasil citra dari 7 printer dapat dilihat pada tabel 2 .

Dari serangkaian uji coba diperoleh citra mikroskop dari dokumen tercetak. Kemudian hasil citra asli yang diperoleh dari USB Microscope dengan

Tabel 2 Citra digital mikro untuk dokumen tercetak dengan pembesaran 1500x

\begin{tabular}{|c|c|c|c|}
\hline Merk Printer & Citra huruf "a" $1500 x$ & $\begin{array}{c}8 \text { bit threshold Serbuk } \\
\text { Toner }\end{array}$ & $\begin{array}{l}\text { Jumlah } \\
\text { Partikel }\end{array}$ \\
\hline HP Las erJet 4200tn & & & 9 \\
\hline $\begin{array}{c}\text { HP Color LaserJet CM2320 } \\
\text { fxi }\end{array}$ & & & 22 \\
\hline Las erJet P2015d & & & $\bigoplus$ \\
\hline HP Las erJet 4300 & & & 4 \\
\hline $\begin{array}{l}\text { LaserJet Pro } 400 \text { Color } \\
\text { M451dn }\end{array}$ & & & 9 \\
\hline HP Color LaserJet CP3525dn & & & 10 \\
\hline HP Las erJet 1300 & & & 7 \\
\hline
\end{tabular}

Sumber: Visualisasi Digital Microscope 
pembesaran 500x dan 1500x diproses dengan Fiji/ ImageJ dikonversi ke dalam threshold grayscale 8 bit dan dihitung jumlah partikelnya. Berdasarkan Tabel 1, bentuk citra digital mikro dengan pembesaran 500x memperlihatkan perbandingan hasil huruf "a" dari 7 jenis printer yang berbeda. Setiap dokumen menghasilkan bentuk partikel yang berbeda tergantung jenisnya. Tabel 2 memperlihatkan bentuk citra digital mikro dengan pembesaran $1500 x$ memperlihatkan perbandingan hasil citra huruf "a" yang dihasilkan dari 7 printer berbeda.
1. Analisis Partikel

Data pada Tabel 1 dan Tabel 2 adalah hasil analisis partikel yang menunjukkan semua arsip tercetak merupakan hasil citra huruf "a" dari 7 cetakan printer yang memiliki jumlah partikel kontras yang bisa dibedakan bentuk dan ukuran partikelnya. Hasil citra digital dengan menggunakan perbesaran 500x tampak terdapat perbedaan arsip tercetak pada huruf ' $a$ ' yang dicetak dengan printer yang berbeda. Perbedaan yang paling signifikan dari hasil arsip tercetak yaitu pada citra dari printer HP LaserJet CM2320fxi, teksturnya terlihat lebih

Tabel 3 Histogram huruf "a" untuk pembesaran 500x

\begin{tabular}{|c|c|c|c|}
\hline Merk Printer & Histogram & Merk Printer & Histogram \\
\hline HP LaserJet 4200tn & LaserJet Pro 400 Color \\
M451dn & HP Color LaserJet CP3525 \\
HP Color LaserJet \\
CM2320 fxi
\end{tabular}

Sumber: Visualisasi gambar hasil dari Fiji/ ImageJ 
Khazanah: Jurnal Pengembangan Kearsipan, 2020, Vol. 13 (2)

Tabel 4 Histogram huruf "a" untuk pembesaran 1500x

\begin{tabular}{|c|c|c|c|}
\hline Merk Printer & Histogram & Merk Printer & Histogram \\
\hline HP LaserJet 4200tn & & $\begin{array}{c}\text { LaserJet Pro 400 Color } \\
\text { M451dn }\end{array}$ \\
\hline HP Color LaserJet \\
CM2320 fxi
\end{tabular}

Sumber: Visualisasi gambar hasil dari Fiji/ ImageJ

semburat daripada citra yang dihasilkan printer lain. Partikel citra arsip tercetak yang dihasilkan HP LaserJet CM2320fxi lebih menyebar dibanding citra lain yang partikelnya lebih padat.

Hasil citra digital dengan menggunakan perbesaran $1500 x$ tampak terdapat perbedaan arsip tercetak pada huruf 'a' yang dicetak dengan printer yang berbeda dapat dilihat pada Tabel 2. Printer HP LaserJet CM2320fxi menampakkan perbedaan signifikan. Teksturnya terlihat lebih semburat daripada citra yang dihasilkan printer lain. Bila dibandingkan dengan partikel citra yang lain, partikel citra arsip tercetak yang dihasilkan HP LaserJet CM2320fxi lebih menyebar dibanding citra lain yang partikelnya lebih padat.

2. Analisis Histogram

Berdasarkan histogram pada Tabel 3 dan tabel 4, dari semua jenis arsip tercetak yang dihasilkan oleh printer yang berbeda menunjukkan intensitas histogram yang berbeda. Misalnya pada printer HP LaserJet 1300 menghasilkan nilai mean 129.870 dengan standar deviasi 83.850 dari minimal citra berada pada range nilai intensitas 0-240. Hasil berbeda dengan hasil dari huruf arsip yang dicetak dari printer HP LaserJet 4200tn yang menghasilkan nilai mean 143.968 
dengan standar deviasi 89.135 dari minimal citra berada pada range nilai 0 255.

Hasil analisis histogram dari semua jenis arsip tercetak yang dihasilkan oleh printer yang berbeda menunjukkan intensitas histogram yang berbeda. Misalnya pada printer HP Color LaserJet CP3525dn menghasilkan nilai mean 180.170 dengan standar deviasi 65.459 dari minimal citra berada pada range nilai intensitas 72-254. Hasil berbeda dengan hasil dari huruf arsip yang dicetak dari printer HP LaserJet 4300 yang menghasilkan nilai mean 178.619 dengan standar deviasi 68.842 dari minimal citra berada pada range nilai 78-255.

Maraknya pemalsuan arsip tercetak mendorong peneliti melakukan autentikasi arsip tercetak menggunakan mikroskop digital. Telah diketahui bahwa arsip tercetak mempunyai nilai yang sangat berharga. Arsip tercetak seperti surat keterangan, sertifikat, ataupun ijazah, serta bentuk arsip tercetak lainnya sebaiknya menggunakan satu jenis printer dengan merk dan tipe atau model tertentu untuk memudahkan penentuan orisinalitas suatu arsip yang diterbitkan oleh suatu instansi atau lembaga tertentu. Penggunaan printer yang berubah merk dari tahun ke tahun akan menyulitkan penentuan orisinalitas suatu arsip atau dokumen jika terjadi pemalsuan. Metode ini digunakan sebagai bukti konkrit jika terjadi pemalsuan arsip. Dengan cara ini keaslian arsip tercetak tersebut dapat dengan mudah diketahui.

Printer yang berbeda akan menunjukkan citra arsip tercetak yang berbeda pula sehingga keaslian suatu arsip tercetak terbukti. Citra arsip tercetak yang sudah diolah peneliti dapat dilakukan dengan analisis partikel dan analisis histogram, sehingga pemalsuan arsip tercetak akan diketahui. Instansi terkait yang mengeluarkan arsip tercetak bisa menggunakan printer dengan merk dan jenis yang sama agar mengurangi pemalsuan arsip tercetak. Demikian pula, instansi bias dapat menggunakan double printing, yaitu menggunakan dua printer yang berbeda dalam satu arsip tercetak agar lebih menguatkan bukti jika ada pemalsuan arsip tercetak tersebut.

\section{KESIMPULAN}

Penelitian proses pencetakan printer pada arsip tercetak meliputi komposisi toner atau serbuk tinta yang mengandung partikel pada karakteristik huruf berbeda tergantung dengan jenis merk printer dan tipenya. Metode autentikasi arsip yang tepat untuk menentukan keaslian suatu berkas surat yang dicetak menggunakan printer merk dan jenis tertentu dapat diketahui dengan melihat perbandingan histogram antar partikel toner pada microscopic images. Hasil yang diperoleh menunjukkan bahwa 
adanya perbedaan bentuk gambar dengan karakteristik dari huruf yang dihasilkan tiap printer berbeda bentuk partikel dan ukurannya. Demikian juga, adanya kesamaan bentuk dan coraknya jika huruf pada arsip tercetak dicetak dengan menggunakan printer yang sama. Penelitian ini memiliki kelemahan terutama dalam penggunaan jenis mikroskop yang terbatas pada magnification $1500 \mathrm{x}$ terlihat blur atau tidak dapat fokus. Untuk itulah dibutuhkan mikroskop dengan tingkat resolusi yang pastinya lebih tinggi untuk hasil yang lebih baik dan jelas citra mikronya.

\section{DAFTAR PUSTAKA}

Bulan, Orhan, Junwen Mao, dan Gaurav Sharma. (2009). Geometric distortion signatures for printer identification," in Proc. IEEE Int. Conf. Acoustics, Speech and Signal Processing, 1401-1404.

Chiang, Pei-Ju, Nitin Khanna, Aravind K. Mikkilineni, Maria V. Ortiz Segovia, Jan P. Allebach, George T. C. Chiu, Edward J. Delp. (2010). Printer and Scanner Forensics: Models and Methods. Intelligent Multimedia Analysis for Security Applications. 145-147.

Fanani, Ardian. (2019). Sindikat Pemalsu Dokumen Digulung, Satu Pelaku Berstatus PNS. sumber: dari https://news.detik.com/berita-jawatimur/d-4927978/sindikat-pemalsudokumen-digulung-satu-pelaku- $\begin{array}{llllllllll}\mathrm{b} & \mathrm{e} & \mathrm{r} & \mathrm{s} & \mathrm{t} & \mathrm{a} & \mathrm{t} & \mathrm{u} & \mathrm{s} & -\end{array}$ pns? ga $=2.24564730 .1994510708 .1583$ 597165-761559593.1583463138. 2 Maret 2020.

Ferreira, Anselmo. L. Bondi, L. Baroffio, P. Bestagini, J. Huang, J. dos Santos, S. Tubaro, and A. Rocha. (2017). Data-driven feature characterization techniques for laser printer attribution, IEEE Transactions on Information Forensics and Security.

Ferreira, Anselmo, L. C. Navarro, G. Pinheiro, J. A. dos Santos, dan A. Rocha. (2015). Laser printer attribution: Exploring new features and beyond. Forensic science international, (247), 105-125.

Hrytsenko, Olha, Dmytro Hrytsenko, Vitaliy Shvalagin, Galyna Grodziuk dan Nataliia Andriushyna. (2017). The influence of parameters of ink-jet printing on photoluminescence properties of nanophotonic labels based on Ag nanoparticles for smart p a c k a ging, Journal of Nanomaterials, vol. 2017, Article ID 3485968.9.

Hrytsenko, Olha, Vitaliy Shvalagin, Galyna Grodziuk, dan Vasyl Granchak. (2017). Influence of parameters of screen printing on photoluminescence properties of nanophotonic labels for smart packaging," Journal of Nanotechnology, vol. 2017, Article ID 7125682. 12.

Jung, Minhun, Junseok Kim, Hyunmo Koo, Wookyu Lee, Vivek Subramanian dan Gyoujin Cho. (2014). Roll-to-roll gravure with nanomaterials for printing smart packaging," Journal of Nanoscience 
and Nanotechnology, 14 (2), 1303-1317.

Kurniati, Florentina Tatrin. (2015). Pengembangan Printer Forensik Untuk Identifikasi Data Dokumen Cetak. Program Studi Magister Teknik Informatika, Program Pascasarjana Universitas Atma Jaya Yogyakarta. Diakses dari http://ejournal.uajy.ac.id/7549/1/MTF00200 7.pdf.

Kurniati, Florentina Tatrin dan Roy Rudolf Huizen (2017). Anomali Fitur Dokumen Cetak untuk Verifikasi di Printer Forensik. Konferensi Nasional Sistem \& Informatika 2017, STMIK STIKOM Bali, 10 Agustus 2017. Sumber: http://knsi.stikomBali.ac.id/index.php/eproceedings/ar ticle/download/156/147/. Diakses pada 12 Maret 2020.

Mikkilineni, A. K., Ali G. N., Chiang P.-J., Chiu, J. P. Allebach, and E. J. Delp. (2004). "Signature-embedding in printed documents for security and forensic applications," Proceedings of the SPIE International Conference on Security, Steganography, and Watermarking of Multimedia Contents VI, vol. 5306, San Jose, CA. 455-466.

Min-Jen Tsai, I. Yuadi, and Y.-H. Tao, "Decision-theoretic Model to Identify Printed Sources," Multimedia Tools and Applications, (2018), 1-45.

Saputra, Andhika Dwi. (2020). Tiga Pemalsu Dokumen untuk Pengurusan Paspor di Kediri Dibekuk. Sumber https://news.detik.com/berita-jawatimur/d-4925325/tiga-pemalsudokumen-untuk-pengurusan-paspor- d i - $\quad$ k e d i r i dibekuk? ga $=2.124164426 .1994510$ $\begin{array}{lllllllllllll}7 & 0 & 8 & 1 & 5 & 8 & 3 & 5 & 9 & 7 & 1 & 6 & 5\end{array}$ 761559593.1583463138 .2 Maret 2020 .

Shang, Shize, Xiangwei Kong, dan Xingang. 2015. Document forgery detection using distortion mutation of geometric parameters in characters, Journal of Electronic Imaging, 24 (2), 023 008-023008.

Velarosdela, Rindi Nuris. 2019. Polisi Tangkap Pemalsu Dokumen Negara, Beroperasi Selama 8 Tahun. Sumber: https://megapolitan.kompas.com/rea d/2019/09/19/16432991/polisitangkap-pemalsu-dokumen-negaraberoperasi-selama-8-tahun. 2 Maret 2020.

Wu, Han, Xiangwei Kong, and Shize Shang, 2015. A printer Forensics Method using Halftone Dot Arrangement Model. IEEE China Summit and International Conference on Signal and Information Processing (ChinaSIP). 861-865. 